\title{
Quantum Dot-sensitized Solar Cells: A Review
}

\author{
Pooja Bhambhani \\ Department of Physics, Banasthali Vidyapith, Rajasthan, 304022, India
}

\begin{tabular}{l} 
Article Info \\
\hline Article history: \\
Received Oct 22, 2017 \\
Revised Dec 23, 2017 \\
Accepted Jan 06, 2018 \\
\hline Keywords: \\
Multiple Exciton Generation \\
(MEG) \\
Power conversion efficiency \\
QDSSC \\
Quantum confinement
\end{tabular}

\begin{abstract}
Quantum dot-sensitized solar cell (QDSSC) has an analogous structure and working principle to the dye sensitizer solar cell (DSSC). It has drawn great attention due to its unique features, like multiple exciton generation (MEG), simple fabrication and low cost. The power conversion efficiency (PCE) of QDSSC is lower than that of DSSC. To increase the PCE of QDSSC, it is required to develop new types of working electrodes, sensitizers, counter electrodes and electrolytes. This review highlights recent developments in QDSSCs and their key components, including the photoanode, sensitizer, electrolyte and counter electrode.
\end{abstract}

Copyright (ㅇ 2018 Institute of Advanced Engineering and Science. All rights reserved.

\section{Corresponding Author:}

Pooja Bhambhani

Department of Physics, Banasthali Vidyapith,

Rajasthan, 304022, India

Email: bpoojaphysics@gmail.com

\section{INTRODUCTION}

Presently, the world has been facing lots of environment problems such as overpopulation, climate changes, natural resource depletion, deforestation, global warming, and ozone layer depletion [1]. Out of these problems, one of the main problems is depletion of natural resources that makes us to think about renewable energy sources. Renewable energy plays an important role in reducing green-house gas emission. To reduce the demand for fossil fuels, renewable energy sources are supposed to be focused [2], [3]. Many renewable energy sources have been reported like hydropower, wave power, photovoltaic cell and wind turbine. Out of these sources, solar cells can be considered as a enormous source of renewable energy [4], [5]. Sunlight is the most abundant, cleanest, cheap and safe energy source [6], [7].

The conversion of sunlight into electrical signal is known as photovoltaic effect. It was first renowned in 1839 by French Physicist A.E. Becquerel. In 1983, Charles Fritts built first photovoltaic cell by using selenium semiconductor coated with an extremely thin layer of gold to form the junctions. There after various changes have occurred in mechanism of solar cells. PV cells are basically classified in three classes depending on their technology. First generation solar cell is based on single- and poly- crystalline silicon [8]. Second generation PV cells are based on amorphous silicon [9], CdTe [10], Cu(InGe)Se2 [11] and III-V semiconductors thin film [12]. Second generation PV cells have lower cost than first generation PV cells; but their efficiency is lower than previous ones. Research on third generation PV cells is essential to achieve solar cells, which have higher power conversion efficiency with lower fabrication cost. Much new kind of solar cells has been proposed like Dye-sensitizer solar cells (DSSCs) [13], organic solar cells [14] and Quantum dots- sensitizer solar cells (QDSSCs) [15]. DSSCs have poor conversion efficiency because of poor optical absorption of sensitizers. The dye molecules generally degrade with the exposure of infrared and ultraviolet radiations, exposure to air; water, UV light, heat and other chemicals can lead to degradation over time which leads the instability of DSSCs [16]. Quantum dots-sensitizer solar cells (QDSSCs) are considered 
as an alternative of DSSCs which have been studied extensively over the past two decades because of exception optical properties of quantum dots [17]-[20].

\section{SPECIAL FEATURES OF QUANTUM DOTS}

Quantum dots (QD's) are semiconductor nanomaterials having size less than $10 \mathrm{~nm}$. Structural, electrical, mechanical and optical properties of bulk material depend on type of material only even these properties of QD are function of material as well as shape and size also, hence by altering the shape and size of nanostructures, their properties may be altered in accordance with application. There are two basic reasons because of that, properties of nanostructures change with their shape and size: quantum confinement effect and increment of volume to surface area ratio [21]. Various QD's such as CdS [22], CdSe [23], PbS [24], PbSe [25] have been used as sensitizer in QDSSCs. QDs have special features like Multiple exciton generation (MEG) of carrier [26], tunable optical band gap and broad optical absorption regions of solar spectrum [27], Hot electron injection [28].

\subsection{Multiple Exciton Generation (MEG)}

Material can absorb only fixed amount of energy from incident photon. If a photon having energy more than energy band gap of semiconductor is incident on that semiconductor then excess energy is lost in the form of heat. The conversion efficiency of traditional solar cells is less because of lost of excess energy in form of heat. MEG in QDs is the one way by which power conversion efficiency of QDSSCs can be enhanced. The production of two or more electron-hole pairs by one photon excitation is known as MEG effect. In conventional case, only one electron-hole pair produces by one photon excitation irrespective to energy of photon whereas in case of QDSSC, if energy of incident photon is Eg, 2Eg or 3Eg then one, two or three electron-hole pairs, respectively, produce [Figure 1] because MEG takes place in QDs. A photon with energy at least twice the energy band gap of QDs is required for MEG. Nozik has predicted that the theoretic power conversion efficiency of QDSSCs to be as high as 42\% [29], which is higher than the ShockleyQueisser efficiency limit of $31 \%$, for the conventional single junction solar cell [30]. MEG effect can be observed in bulk semiconductor also but the required threshold energy of photon for bulk semiconductor is much higher than that for QDs. The threshold energy of photon for bulk $\mathrm{PbSe}$ is $6.5 \mathrm{Eg}$ whereas that for $\mathrm{PbSe}$ $\mathrm{QD}$ is 3.4Eg (Eg is the energy band gap of PbSe). The basic concept of MEG in QDs is shown in Figure 2.

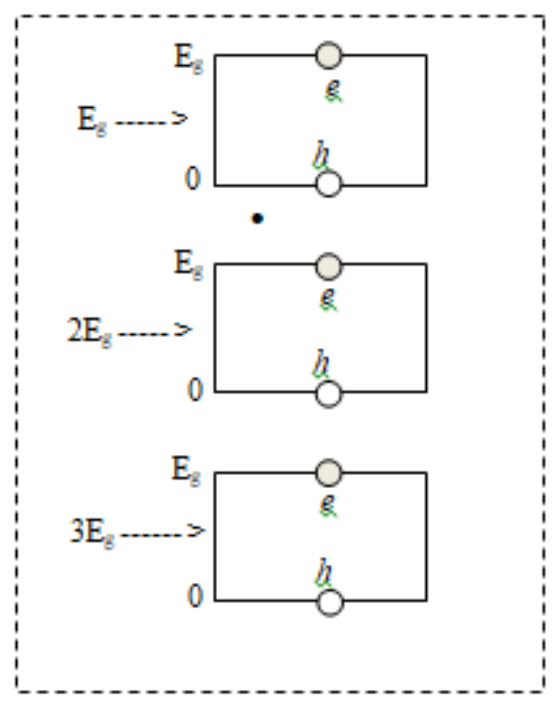

(a)

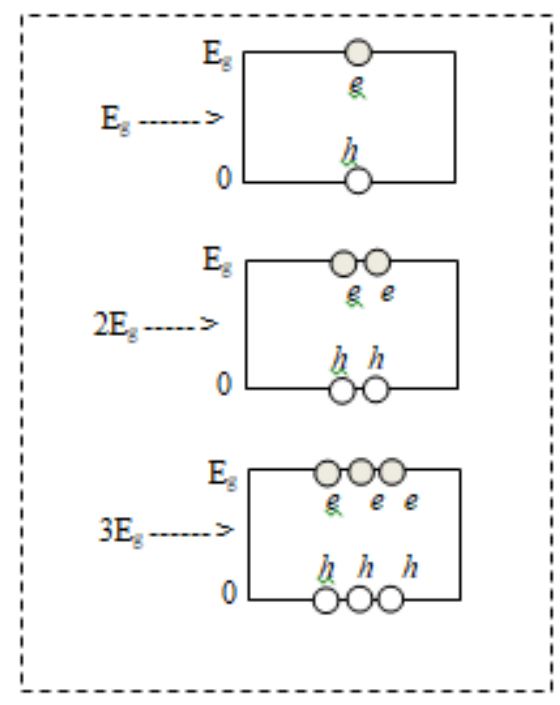

(b)

Figure 1. (a) Traditional solar cell and (b) Multiple excitons generation 


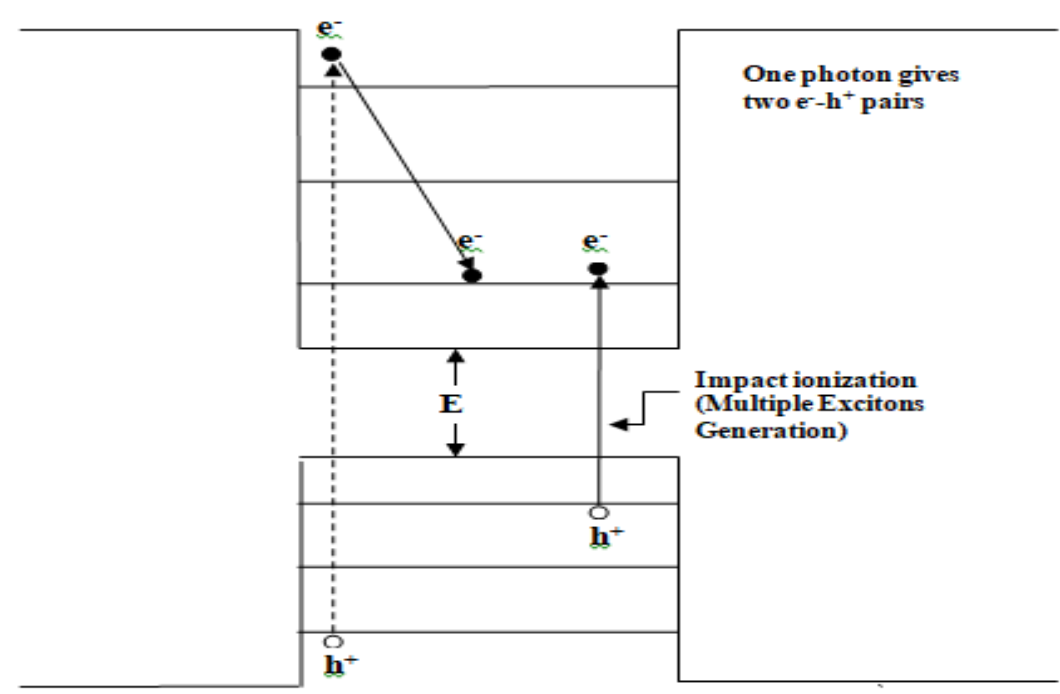

Figure 2. Enhanced photovoltaic efficiency in QDSSC by Multiple Exciton Generation (MEG) [29]

\subsection{Size-dependant Band Gap}

QDs are used as sensitizer in QDSSC because of their specific optical characteristic that is sizedependant energy bang gap. If the size of QDs has been changed, light harvesting energy can be controlled [32]. Along with it, an effective charge separation is also possible by tuning the size of QDs. quantum confinement effect of QDs is the main reason of size dependency of band gap [33]. If the size of quantum dot is smaller than the critical characteristic length, called the Bohr exciton radius, strong confinement effect takes place. Nonocrystals behave differently from their corresponding bulk material because of quantum confinement effect. The Bohr exciton radius of most of the semiconductor is in the range of $1 \sim 10 \mathrm{~nm}$, for example it is $2 \mathrm{~nm}$ for $\mathrm{ZnO}$ [34], $3 \mathrm{~nm}$ for CdS [35], $5.3 \mathrm{~nm}$ for CdSe [36]. However, some semiconductors have large Bohr exciton radius like it is $18 \mathrm{~nm}$ for $\mathrm{PbS}$ [37], $46 \mathrm{~nm}$ for PbSe [38] and $65.6 \mathrm{~nm}$ for InSb [36]. Strong confinement effect can be easily achieved in those semiconductors which have large exciton radius. Energy band gap (Eg) of QD increases with reduction in their size [39]. Eg can be explicated by Eg $\alpha 1 \backslash \mathrm{r} 2$, where $r$ is the radius of QD. If the energy band gap of QD increases $\backslash$ decreases, it will absorb photon of higher energy (lower wavelength) \lower energy (higher wavelength) to be excited. It means that the range of optical absorption wavelength can be tuned by altering the size of QD. Lee et. al. [40] has reported that energy of bottom of conduction band $(\mathrm{Ecb})$ of QD moves up with the QD size reduction due to the quantum confinement effect. Figure 3[41] shown the strong significance of quantum confinement effect on performance of QDSSC.

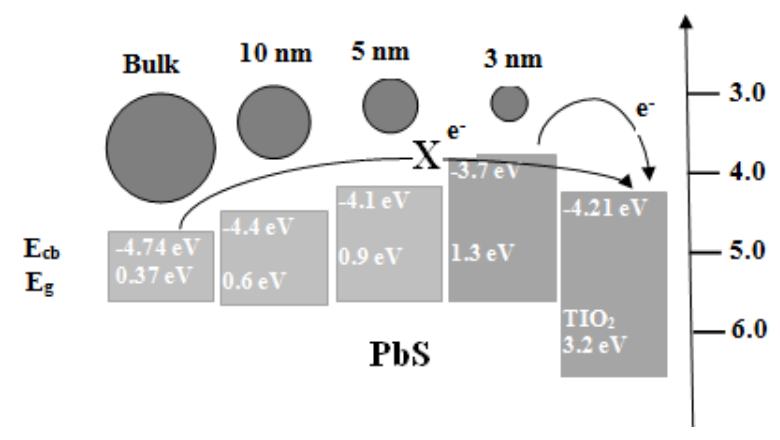

Figure 3. Schematic illustration of the modulation of energy levels of $\mathrm{PbS}$ by particle size [41]

As shown in Figure 3, the Ecb of bulk $\mathrm{PbS}$ is $-4.74 \mathrm{eV}$, which is lower than that of $\mathrm{TiO}_{2}(-4.21 \mathrm{eV})$, hence movement of electron from conduction band of $\mathrm{PbS}$ to that of $\mathrm{TiO}_{2}$ is not possible. As the size of $\mathrm{PbS}$ reduces, bottom of conduction band move to higher energy. When the size of PbS QD is $5 \mathrm{~nm}$, its Ecb is at $4.1 \mathrm{eV}$, hence the transfer of electron from conduction band of $\mathrm{PbS} \mathrm{QD}$ to that of $\mathrm{TiO}_{2}$ is easily possible. In 
short, quantum confinement effect is must for QDSSC. Different photovoltaic parameters of QDSSC with the QDs of different diameter are summarized in Table 1.

Table 1. Photovoltaic Parameters of QDSSCs Based on Different Diameter of QDs

\begin{tabular}{cccccc}
\hline Quntum Dots & Diameter of QDs $(\mathrm{nm})$ & $\mathrm{Jsc}\left(\mathrm{mAcm}^{-2}\right)$ & Voc $(\mathrm{V})$ & PCE (\%) & Ref \\
\hline CdS & 4.4 & 3.519 & 0.41 & 0.66 & {$[42]$} \\
CdS & 4.9 & 4.519 & 0.44 & 0.85 & {$[42]$} \\
CdS & 5.9 & 6.694 & 0.48 & 1.29 & {$[42]$} \\
CdS & 6.2 & 5.494 & 0.51 & 1.05 & {$[42]$} \\
CdSe (I) & 2.5 & 2.25 & 0.59 & 0.86 & {$[43]$} \\
CdSe(II) & 3.5 & 3.23 & 0.64 & 0.86 & {$[43]$} \\
CdSe(I)/CdSe(II) & $2.5 / 3.5$ & 3.41 & 0.66 & 1.26 & {$[43]$} \\
CdSe/N719 & 2.2 & 2.37 & 0.75 & 0.71 & {$[44]$} \\
CdSe/N719 & 2.5 & 6.42 & 0.78 & 3.31 & {$[44]$} \\
CdSe/N719 & 3.3 & 6.95 & 0.81 & 3.65 & {$[44]$} \\
\hline
\end{tabular}

Jung Sung Woo et al. [42] reported that Photocurent increases with the size of CdS QD because CdS QD-assembled $\mathrm{TiO}_{2}$ films were fully covered by large CdS QDs, which reduces recombination between $\mathrm{TiO}_{2}$ and electrolyte whereas with the increase of QD size, electron transfer rate reduces, hence the size of QDs should be optimized for better performance. In order to increase the power conversion efficiency of QDSSC, band structure of QD should be matched with that of oxide film and optical absorption wavelength range should be wide.

Under such consideration, construction of rainbow solar cell is an approach towards high efficient QDSSC. In rainbow solar cell, QDs with two or more different sizes are employed instead of single-sized QD. Chen et al [43] has reported efficiency of QDSSC with two different sized QD (1.26\%) is higher than that with single-sized QD (1\%). As white light is incident on cell, smaller sized QDs (larger energy band gap) absorb smaller wavelength region (blue region) of white light, light with longer wavelength (red region) which is transmitted through initial layer is absorbed by subsequent layer of bigger sized QDs. By using different sized QDs, optical absorption wavelength range can be enhanced.

\section{STRUCTURE OF QDSSC}

The basic structure of QDSSC is shown in Figure 4.

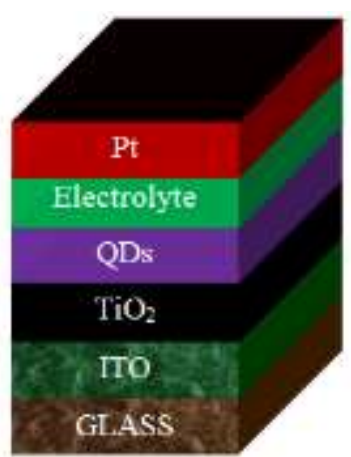

Figure 4. Basic structure of QDSSC

The typical QDSSC has four major parts:

1) Photoanode

2) Sensitizer (Quantum dots)

3) Electrolyte

4) Counter electrode

\subsection{Photoanode}

Photoanode usually consists of semiconducting metal oxide deposited on a transparent conducting oxide (TCO) substrate, typically fluorine-doped tin oxide (FTO) glass. TCO substrate in QDSSC supports the 
semiconductor layer and works as a current collector. For an idea TCO substrate, optical transparency should be high and electrical resistivity should be low. Transmission of sunlight through substrate become smooth without any unwanted optical absorption due to high transparency of substrate and to facilitate the charge transfer process and to reduce energy loss, low electrical resistivity of TCO substrate is must [45].

Photoanode is an important part in QDSSC because it works as a matrix for QD adsorption and provides a charge transport medium for transportation of electrons from sensitizer to TCO substrate. To achieve better QD adsorption and smooth transportation of electrons from sensitizer to TCO substrate without undergoing recombination, photoanode should have following characteristics:-

a. High electron mobility to achieve smooth electron transport.

b. High surface area for maximum QD loading, hence effective light absorption takes place.

c. High transparency to reduce unwanted adsorption of incident photon.

d. Does not react with redox electrolyte to reduce recombination rate.

Titanium dioxide $\left(\mathrm{TiO}_{2}\right)$ is found most promising semiconductor material for photoanode in QDSSC, because of its specific features like wide band gap ( 3.2eV) [46], low cost [47], nontoxic, high chemical stable, mesoporous nature [48, 49]. Along with these features, $\mathrm{Tio}_{2}$ has higher $\mathrm{CB}$ edge, surface area and electron affinity, compared with other metal oxides, which make it the most suitable material for photoanode in QDSSC.

$\mathrm{TiO}_{2}$ exists in three crystalline forms, namely rutile (tetragonal), anatase (tetragonal) and brookite (orthorhombic) [50]. Out of these forms, rutile is the most thermodynamically stable form. However, anatase is more preferred in QDSSC because of its better efficiency for solar energy conversion and photo-catalysis [51]. Zhang et al. [52] have reported that rutile and brookite belong to direct band gap semiconductor category, while anatase is direct bang gap semiconductors. In anatase, the direct transition of photoexcited electrons from conduction band (CB) to valence band (VB) is impossible because of its indirect band gap. Consequently, the lifetime of photoexcited electrons is longer in anatase compared with brookite and rutile. In addition, the average effective mass of photoexcited electrons of anatase is also the lightest among the three forms of $\mathrm{Tio}_{2}$, which results faster migration of photoexcited electrons and hence lower recombination rate in anatase compared with other two forms [52]. Park et al.[53] reported that anatase-based solar cell has higher short-circuit photocurrent (Jsc) than rutile-based solar cell, whereas the open-circuit voltage (Voc) is the similar for both the cells. Rutile-based cell has lower photocurrent because its film has smaller surface area compared with anatase film, hence absorption of QDs is lower in rutile film.

Thin films made of sintered $\mathrm{TiO}_{2}$ nanoparticles ( 20 nm diameter) are extensively used as photoanode for QDSSCs due to their large surface area that is desired for the adsorption of QDs. on the other hand, there are two major drawbacks of these conventional sintered $\mathrm{TiO}_{2}$ photoanode. First, the scattering of incident light is negligible because the size of the $\mathrm{TiO}_{2}$ nanoparticles is much smaller than the wavelength range of the absorbed solar irradiations; hence probability of photon-QDs interaction reduces. Second, the transport of carriers through complex networks of sintered nanoparticles is not smooth because several grain boundaries between sintered nanoparticles arise that enhance recombination and very slow migration of carriers [54].

Various one-dimensional nanostructures such as nanowire [55], [56], nanorod [57], [58] and nanotube [59], [60] have been reported as photoanodes for enhancing the transport of electrons by providing direct conduction pathways with reduced recombination at the grain boundaries and trapping. However, these one-dimensional nanostructures have smaller surface area of nanoparticle which makes less absorption of QDs on photoanode, i.e. less light harvesting. To enhance light scattering and transport of charge carriers, different nanostructure of $\mathrm{TiO}_{2}$ has been reported as photoanode in QDSSC. Anita Kolay et al [61] compared the photovoltaic performances of QDSSCs having different morphologies of $\mathrm{TiO}_{2}$. They considered four morphologies: porous nanoparticles (PNPs), nanowires (NWs), nanosheets (NSHs) and nanoparticles (NPs). The reported order of average magnitudes of PCEs: NWs $(5.96 \%)$, NPs (4.95\%), PNPs (4.85\%), NSHs $(2.5 \%)$. Y.B. Lu. et al. [62] reported the $1 \mathrm{D}$ connected $\mathrm{TiO}_{2}$ nanoparticles (1D CTNPs) as photoanode sensitized solar cells. This idea combines the advantages of $\mathrm{TiO}_{2}$ nanoparticles (high specific surface area) and one-dimensional (1D) nanostructures (fast transport channels) for obtaining highly efficient sensitized solar cells. To evaluate the effects of the 1D CTNPs on the performance of CdSe QDSSCs, another CdSe QDSSC was fabricated based on conventional $\mathrm{TiO}_{2}$ nanoparticles (TNPs). The light-to-electricity conversion efficiency of 1D CTNP-based CdSe QDSSC (5.45\%) is much higher than that of the TNP-based cell (4.00\%). In addition to NPs and NWs, other morphologies, such as nanosheets (NSs), nanorods (NRs), microspheres (MSs), nanotubes (NTs), nanofibers (NFs), mesoporous (MPs), tetrapods (TPs), and nanodisks (NDs), have also been developed for $\mathrm{TiO}_{2}$. Similarly, along with $\mathrm{TiO}_{2}$, other materials like $\mathrm{ZnO}$ [63]-[65], $\mathrm{SnO} 2$ [66], NiO [67] etc have been used as photoanode in QDSSC. Photovoltaic parameters of QDSSCs with different photoanode are summarized in Table 2. 
Table 2. Photovoltaic Parameters and Photoactive Materials of QDSSCs Based on Different Photoanode

\begin{tabular}{|c|c|c|c|c|c|c|c|c|}
\hline Photoanode & $\begin{array}{c}\text { Quantum } \\
\text { dot }\end{array}$ & Electrolyte & $\begin{array}{c}\text { Counter } \\
\text { Electrode }\end{array}$ & $\begin{array}{c}\text { Jsc } \\
\left(\mathrm{mA} \mathrm{cm}^{-2}\right)\end{array}$ & $\begin{array}{c}\mathrm{V}_{\mathrm{oc}} \\
(\mathrm{mV})\end{array}$ & $\mathrm{FF}$ & $\begin{array}{l}\text { PCE } \\
(\%)\end{array}$ & Ref \\
\hline $\mathrm{TiO}_{2} \mathrm{NPs}$ & $\mathrm{CdSe} / \mathrm{ZnS}$ & $\mathrm{S}^{2-} / \mathrm{S}_{\mathrm{x}}^{2-}$ & $\mathrm{Cu}_{2} \mathrm{~S}$ & 15.54 & 56.3 & 0.61 & 5.53 & [69] \\
\hline $\mathrm{TiO}_{2} \mathrm{NSs}$ & $\begin{array}{c}\mathrm{CdSe} / \mathrm{ZnS} / \\
\mathrm{SiO}_{2}\end{array}$ & $\mathrm{~S}^{2-} / \mathrm{S}_{\mathrm{x}}{ }^{2-}$ & $\mathrm{Cu}_{2} \mathrm{~S}$ & 16.95 & 591 & 0.50 & 5.01 & [70] \\
\hline $\mathrm{TiO}_{2} \mathrm{NRs}$ & $\mathrm{CdSe} / \mathrm{ZnS}$ & $\mathrm{S}^{2-} / \mathrm{S}_{\mathrm{x}}{ }^{2-}$ & $\begin{array}{c}\mathrm{Cu}_{2} \mathrm{ZnSn} \\
\mathrm{S}(\mathrm{Se})\end{array}$ & 17.5 & 563 & 0.605 & 5.96 & [71] \\
\hline $\mathrm{TiO}_{2} \mathrm{NTs}$ & $\begin{array}{c}\mathrm{CdS} / \mathrm{CdSe} / \\
\mathrm{ZnS}\end{array}$ & $\mathrm{S}^{2-} / \mathrm{S}_{\mathrm{x}}{ }^{2-}$ & $\mathrm{Cu}_{2} \mathrm{~S}$ & 10.81 & 689 & 0.62 & 4.61 & [72] \\
\hline $\mathrm{TiO}_{2} \mathrm{NWs}$ & $\mathrm{CdS} / \mathrm{CdSe}$ & $\mathrm{S}^{2-} / \mathrm{S}_{\mathrm{x}}^{2-}$ & $\mathrm{Pt}$ & 17.98 & 465 & 0.502 & 4.20 & [73] \\
\hline ZnO NWs & $\begin{array}{c}\mathrm{CdS} / \mathrm{CdSe} / \\
\mathrm{ZnS}\end{array}$ & $\mathrm{S}^{2-} / \mathrm{S}_{\mathrm{x}}^{2-}$ & $\mathrm{Au}$ & 17.3 & 627 & 0.383 & 4.15 & [63] \\
\hline $\mathrm{ZnO}$ NRs & $\mathrm{CdS} / \mathrm{CdSe}$ & $\mathrm{S}^{2-} / \mathrm{S}_{\mathrm{x}}{ }^{2-}$ & $\mathrm{Cu}_{2} \mathrm{~S}$ & 9.93 & 0.61 & 0.52 & 3.14 & [64] \\
\hline $\mathrm{ZnO}$ NDs & $\mathrm{CdS} / \mathrm{CdSe}$ & $\mathrm{S}^{2-} / \mathrm{S}_{\mathrm{x}}^{2-}$ & $\mathrm{Pt}$ & 16.0 & 620 & 0.49 & 4.86 & [65] \\
\hline $\mathrm{TiO}_{2}$ NFS-ZnO NSs & $\begin{array}{c}\mathrm{CdS} / \mathrm{CdSe} / \\
\mathrm{ZnS}\end{array}$ & $\mathrm{S}^{2-} / \mathrm{S}_{\mathrm{x}}^{2-}$ & $\mathrm{Cu}_{2} \mathrm{~S}$ & 13.64 & 511 & 0.44 & 3.05 & [74] \\
\hline $\mathrm{TiO}_{2}$ NWS-ZnO NSs & $\mathrm{CdS} / \mathrm{CdSe}$ & $\mathrm{S}^{2-} / \mathrm{S}_{\mathrm{x}}{ }^{2-}$ & $\mathrm{Cu}_{2} \mathrm{~S}$ & 16.11 & 512 & 0.55 & 4.57 & [68] \\
\hline $\mathrm{SnO}_{2}$ & $\begin{array}{c}\mathrm{CdS} / \mathrm{CdSe} / \\
\mathrm{ZnS}\end{array}$ & $\mathrm{S}^{2-} / \mathrm{S}_{\mathrm{x}}^{2-}$ & $\begin{array}{l}\text { Carbon } \\
\text { NFs }\end{array}$ & 7.5 & 587 & 0.562 & 2.5 & [66] \\
\hline $\mathrm{NiO}$ & $\mathrm{CuInS}_{\mathrm{x}} \mathrm{Se}_{2-\mathrm{x}}$ & $\mathrm{S}^{2-} / \mathrm{S}_{\mathrm{x}}{ }^{2-}$ & $\mathrm{Cu}_{2} \mathrm{~S}$ & 9.13 & 350 & 0.39 & 1.25 & [67] \\
\hline
\end{tabular}

\subsection{Sensitizer (Quantum Dots)}

QDs are important part of QDSSC. To maximize the harvesting efficiency of the incident light, it should possess a high absorption coefficient and appropriate band-gap energy. The energy levels of QDs applied in QDSSCs must match those of the sensitized wide band-gap semiconductors. If the band-gap energy of the QDs is high, although a large VOC can be achieved, the wavelength range of light absorption will be narrowed. On the other hand, low band-gap energy of QDs may contribute to a wide wavelength region of light absorption, whereas it may lead to a low VOC [75].

The QDs employed in QDSSCs as sensitizers including Ag2S [76], Bi2S3 [77], CdS [78], CdSe [79], CdTe [80], $\mathrm{CuInS}_{2}$ [81], [82], $\mathrm{Cu} 2 \mathrm{ZnSnS}_{4}$ [83], InAs [84], In2S ${ }_{3}$ [85], InP [86], $\mathrm{PbS}$ [87], [88], $\mathrm{PbSe}$ [89], Si [90], graphene [91] and so on. Among these sensitizers, Cd chalcogenides QDs have drawn great attention because of their relatively high stability in QDSSCs even though they may be unstable under visible light. In addition, co-sensitization of two or three types of QDs, for example, CdS/CdSe [92], CdS/CdTe [93], $\mathrm{CdSe} / \mathrm{CdTe}$ [94], [95], CdS/PbS [96], [97], CdS/CdSe/PbS [of the complementary effect of extending the wavelength range of absorbed light.

There are two fundamental techniques of fabrication of QD sensitizers: in situ fabrication and ex situ fabrication. Chemical bath deposition (CBD) [104] and successive ionic layer adsorption reaction (SILAR) [105] techniques belong to in situ fabrication whereas linker-assisted assembly (LAA) [106] is an example of ex situ fabrication technique. In situ technique is more preferable to ex situ fabrication technique because of its better performance [107]. Photovoltaic parameters of QDSSCs with different QDs are summarized in Table 3.

Table 3. Photovoltaic Parameters and Photoactive Materials of QDSSCs Based on Different QDs

\begin{tabular}{|c|c|c|c|c|c|c|c|c|c|}
\hline Quantum dots & Method & Photoanode & Electrolyte & $\begin{array}{c}\text { Counter } \\
\text { Electrode }\end{array}$ & $\begin{array}{c}\text { Jsc } \\
\left(\mathrm{mAcm}^{-2}\right)\end{array}$ & $\begin{array}{c}\mathrm{V}_{\mathrm{oc}} \\
(\mathrm{mV})\end{array}$ & FF & $\begin{array}{l}\text { PCE } \\
(\%) \\
\end{array}$ & Ref \\
\hline $\mathrm{Ag}_{2} \mathrm{~S} / \mathrm{ZnS}$ & SILAR & $\mathrm{TiO}_{2}$ NPs & $\mathrm{I}^{-} / \mathrm{I}_{3}^{-}$ & $\mathrm{Pt}$ & 28.5 & 270 & 0.238 & 1.76 & [76] \\
\hline $\mathrm{CdS} / \mathrm{Bi}_{2} \mathrm{~S}_{3} / \mathrm{ZnS}$ & SILAR & $\mathrm{TiO}_{2} \mathrm{NPs}$ & $\mathrm{S}^{2-} / \mathrm{S}_{\mathrm{x}}^{2-}$ & $\mathrm{Cu}_{2} \mathrm{~S}$ & 9.3 & 502 & 0.537 & 2.52 & [77] \\
\hline $\mathrm{CdS} / \mathrm{CdSe}$ & ED & $\mathrm{TiO}_{2} \mathrm{MSs}$ & $\mathrm{S}^{2-} / \mathrm{S}_{\mathrm{x}}^{2-}$ & $\mathrm{Pt}$ & 18.23 & 489 & 0.54 & 4.81 & [92] \\
\hline $\mathrm{CuInS}_{2} / \mathrm{ZnS}$ & LAA & $\mathrm{TiO}_{2}$ NPs & $\mathrm{S}^{2-} / \mathrm{S}_{\mathrm{x}}^{2-}$ & $\mathrm{Cu}_{2} \mathrm{~S}$ & 20.65 & 586 & 0.581 & 7.04 & [81] \\
\hline $\mathrm{Cu}_{2} \mathrm{ZnSnS}_{4} / \mathrm{ZnS}$ & LAA & $\mathrm{TiO}_{2}$ NPs & $\mathrm{S}^{2-} / \mathrm{S}_{\mathrm{x}}^{2-}$ & $\mathrm{Cu}_{2} \mathrm{~S}$ & 18.86 & 510 & 0.494 & 4.70 & [83] \\
\hline $\mathrm{CdS} / \mathrm{CdSe} / \mathrm{CdS} / \mathrm{ZnS}$ & CBD/SILAR & $\mathrm{TiO}_{2} \mathrm{NPs}$ & $\mathrm{S}^{2-} / \mathrm{S}_{\mathrm{x}}{ }^{2-}$ & $\mathrm{Cu}_{2} \mathrm{~S}$ & 17.7 & 555 & 0.557 & 5.47 & [78] \\
\hline $\begin{array}{c}\mathrm{CdTe} / \mathrm{CdSe} \mathrm{Te}_{1-} \\
{ }_{x} / \mathrm{ZnS}\end{array}$ & $\begin{array}{l}\text { LAA/ } \\
\text { SILAR }\end{array}$ & $\mathrm{TiO}_{2} \mathrm{NPs}$ & $\mathrm{S}^{2-} / \mathrm{S}_{\mathrm{x}}{ }^{2-}$ & $\mathrm{Cu}_{2} \mathrm{~S}$ & 16.58 & 629 & 0.694 & 7.24 & {$[80]$} \\
\hline $\mathrm{CdTe} / \mathrm{CdSe} / \mathrm{ZnS}$ & LAA & $\mathrm{TiO}_{2} \mathrm{NPs}$ & $\mathrm{S}^{2-} / \mathrm{S}_{\mathrm{x}}{ }^{2-}$ & $\mathrm{Cu}_{2} \mathrm{~S}$ & 19.59 & 606 & 0.569 & 6.76 & {$[95]$} \\
\hline $\mathrm{CdTe} / \mathrm{CdS} / \mathrm{CdS}$ & $\begin{array}{l}\text { LAA/ } \\
\text { SILAR }\end{array}$ & $\mathrm{TiO}_{2} \mathrm{NPs}$ & $\mathrm{S}^{2-} / \mathrm{S}_{\mathrm{x}}{ }^{2-}$ & $\mathrm{Cu}_{2} \mathrm{~S}$ & 20.19 & 610 & 0.51 & 6.32 & [99] \\
\hline $\mathrm{PbS} / \mathrm{CdS} / \mathrm{ZnS}$ & LAA & $\mathrm{TiO}_{2} \mathrm{NPs}$ & $\mathrm{S}^{2-} / \mathrm{S}_{\mathrm{x}}^{2-}$ & $\mathrm{Cu}_{2} \mathrm{~S}$ & 18.81 & 595 & 0.642 & 7.19 & [97] \\
\hline $\mathrm{ZnTe} / \mathrm{CdSe} / \mathrm{ZnS}$ & LAA & $\mathrm{TiO}_{2} \mathrm{NPs}$ & $\mathrm{S}^{2-} / \mathrm{S}_{\mathrm{x}}{ }^{2-}$ & $\mathrm{Cu}_{2} \mathrm{~S}$ & 19.29 & 640 & 0.552 & 6.82 & [103] \\
\hline
\end{tabular}




\subsection{Electrolyte}

Redox electrolytes significantly influence both the efficiency and stability of QDSSCs. It is a medium which transfers charges between counter electrodes and photoanodes for the regeneration of oxidized QDs [108]. The most common electrolyte used in QDSSCs is the iodide/triiodide (I-/I3-) electrolyte, which is prepared by mixing I- and I2 with other additives in suitable organic solvents [109].Cadmium chalcogenide QD-based solar cells are unstable in the iodide/ triiodide electrolyte because of photoanodic dissolution and the formation of cadmium iodide. Although, Several study has been proposed to protect the QDs from bleaching by coating them with protective layers [110], but the overall power conversion efficiency of the cell remained quite low which indicates that suitable alternative electrolytes is required to improve the performance and long-term stability of QDSSC.

Thus, a polysulfide (S2-/Sn2-) redox couple aqueous solution electrolyte is generally used in QDSSCs because it is able to stabilize the cadmium chalcogenides QDs with fine performance of the corresponding QDSSCs [111]. Still, there are some disadvantages of the polysulfide electrolyte; like, the VOC of the resultant QDSSCs is generally low because polysulfide electrode has the relatively high redox potential [112]. To optimize the polysulfide electrolyte, many works have been reported like controlling the concentration of the redox mediator [113], introducing additives e.g., SiO2 [114], poly (vinyl pyrrolidone) (PVP) [115], and guanidine thiocyanate [116], and using a modifying solvent [117]. In order to improve the photovoltaic performance, especially the VOC of QDSSCs, alternative redox couples having relatively low redox potentials, such as Mn poly (pyrazolyl) borate and some organic redox couples have been applied in QDSSCs [118,119]. Unfortunately, the most popular cadmium chalcogenide QDs in these electrolytes are unstable.

Moreover, while using liquid electrolytes in QDSSC, many problems are come across like vapour toxicity problems, sealing problems and long term durability arising from leakages and seal degradation due to the volatility of low-boiling solvents. Thus, quasisolid-state and solid-state electrolytes as alternatives to liquid electrolytes have been developed. Ionic liquids [120], gel electrolytes [121], and hydrogel electrolytes [122] containing redox couples are commonly used as quasi solid-state electrolytes. Organic polymers (e.g. poly (3-hexylthiophene) (P3HT) [123], PVP [124] and poly (ethylene oxide)-poly (vinylidene fluoride) (PEO-PVDF) [125] have been applied in solid state QDSSCs. However, the efficiency of the solid state devices is lower than that of the liquid-junction cells.

\subsection{Counter Electrode}

Counter electrode (CE) plays an important role in performance of QDSSC. It transfers electrons from the external circuit into electrolyte and catalyzes the reduction reaction of the oxidized electrolytes at the electrolyte/CE interface. To achieve a superior electrocatalytic performance, CEs should possess high electrical conductivity, excellent electrocatalytic activity and great stability [126]. The most common material for CE in QDSSCs is $\mathrm{Pt}$ because of its good electrocatalytic ability for the reduction of iodide/triiodide electrolyte. However, when Pt CE is used with polysulfide electrolyte, the performance of resultant solar cell is poor because sulfur atoms would easily adsorb onto the Pt surface, hence conductivity of CE reduces consequently power conversion efficiency of QDSSC reduces [127]. For that reason, alternative CE materials in QDSCs have been extensively investigated, like metal chalcogenides [128-130] carbon-based materials [131-133] and various composites [134-136]. Photovoltaic parameters of QDSSCs with different CEs are summarized in Table 4.

Table 4. Photovoltaic Parameters and Photoactive Materials of QDSSCs Based on different CEs

\begin{tabular}{|c|c|c|c|c|c|c|c|c|}
\hline $\begin{array}{c}\text { Counter } \\
\text { Electrode }\end{array}$ & Photoanode & Quantum dots & Electrolyte & $\begin{array}{c}\mathrm{JSc} \\
\left(\mathrm{mA} \mathrm{cm}^{-2}\right)\end{array}$ & $\begin{array}{c}\mathrm{V}_{\mathrm{oc}} \\
(\mathrm{mV})\end{array}$ & $\mathrm{FF}$ & $\begin{array}{l}\text { PCE } \\
(\%)\end{array}$ & Ref \\
\hline $\mathrm{Cu}_{2} \mathrm{~S} /$ brass & $\mathrm{TiO}_{2} \mathrm{NPs}$ & $\mathrm{CdS} / \mathrm{CdSe} / \mathrm{ZnS}$ & $\mathrm{S}^{2-} / \mathrm{S}_{\mathrm{x}}^{2-}$ & 14.54 & 634 & 0.667 & 6.15 & {$[128]$} \\
\hline CuS NSs & $\mathrm{TiO}_{2} \mathrm{NPs}$ & $\mathrm{CdS} / \mathrm{CdSe} / \mathrm{ZnS}$ & $\mathrm{S}^{2-} / \mathrm{S}_{\mathrm{x}}^{2-}$ & 17.43 & 596 & 0.495 & 5.15 & [129] \\
\hline CuS NPs & $\mathrm{TiO}_{2} \mathrm{NPs}$ & $\mathrm{CdSe} / \mathrm{ZnS}$ & $\mathrm{S}^{2-} / \mathrm{S}_{\mathrm{x}}^{2-}$ & 17.7 & 551 & 0.491 & 4.78 & [130] \\
\hline Carbon NFs & $\mathrm{TiO}_{2} \mathrm{NPs}$ & $\mathrm{CdSe} / \mathrm{ZnS}$ & $\mathrm{S}^{2-} / \mathrm{S}_{\mathrm{x}}^{2-}$ & 11.99 & 620 & 0.60 & 4.81 & [131] \\
\hline Carbon NPs & $\mathrm{TiO}_{2} \mathrm{NPs}$ & $\mathrm{CdS} / \mathrm{CdSe} / \mathrm{ZnS}$ & $\mathrm{S}^{2-} / \mathrm{S}_{\mathrm{x}}^{2-}$ & 13.53 & 510 & 0.40 & 2.67 & [132] \\
\hline Carbon MSs & $\mathrm{TiO}_{2} \mathrm{NPs}$ & $\mathrm{CdSe} / \mathrm{ZnS}$ & $\mathrm{S}^{2-} / \mathrm{S}_{\mathrm{x}}^{2-}$ & 12.41 & 600 & 0.52 & 3.90 & [133] \\
\hline $\begin{array}{l}\text { ITONWs } \\
/ \mathrm{Cu}_{2} \mathrm{~S} \text { NPs }\end{array}$ & $\mathrm{TiO}_{2} \mathrm{NPs}$ & $\mathrm{CdS} / \mathrm{CdSe} / \mathrm{ZnS}$ & $\mathrm{S}^{2-} / \mathrm{S}_{\mathrm{x}}^{2-}$ & 14.31 & 540 & 0.525 & 4.06 & {$[134]$} \\
\hline $\begin{array}{l}\text { CuS NPs } \\
\text { /ZnO NRs }\end{array}$ & $\mathrm{TiO}_{2} \mathrm{NPs}$ & $\mathrm{CdS} / \mathrm{CdSe}$ & $\mathrm{S}^{2-} / \mathrm{S}_{\mathrm{x}}{ }^{2-}$ & 14.48 & 760 & 0.38 & 4.18 & [135] \\
\hline $\begin{array}{l}\text { PbS NPs } \\
\text { /ZnO NRs }\end{array}$ & $\mathrm{TiO}_{2} \mathrm{NPs}$ & $\mathrm{CdS} / \mathrm{CdSe} / \mathrm{ZnS}$ & $\mathrm{S}^{2-} / \mathrm{S}_{\mathrm{x}}{ }^{2-}$ & 13.28 & 633 & 0.566 & 4.76 & [136] \\
\hline
\end{tabular}

BEEI, Vol. 7, No. 1, March 2018 : $42-54$ 


\section{WORKING PRINCIPLE OF ODSSC}

A QDSSC operates in the following processes under illumination as shown in Figure 5:

a. Upon light irradiation, the sensitizer is photoexcited.

b. The excited electrons of QDs are injected into the conduction band of the $\mathrm{TiO}_{2}$.

c. The electrons penetrate through the nanocrystalline $\mathrm{TiO}_{2}$ film to the back contact of the conducting substrate, and flow through an external circuit to the CEs.

d. At the CEs, the oxidized component of redox couple in the electrolyte is reduced.

e. The oxidized form of the sensitizer (QDs) is finally regenerated by the reduced component of redox couple in the electrolyte.

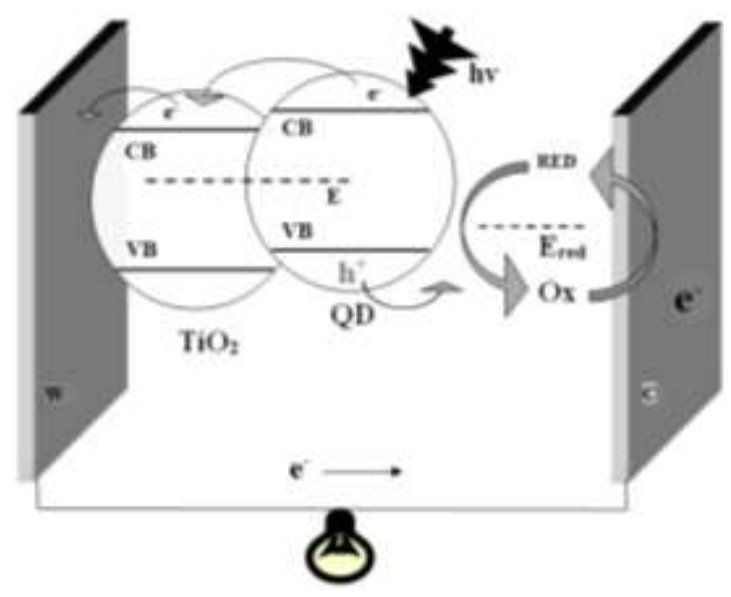

Figure 5: Working principle of QDSSC [137]

In this overall process, there are two major recombination loss processes that limit the total photo conversion efficiency within the QDSSCs: the photoinjected electrons in $\mathrm{TiO}_{2}$ can recombine directly with the oxidized QDs or with the oxidized form of the redox couple in the electrolyte.

\section{CONCLUSION}

Over the past few years, QDSSCs have been the subject of extensive studies for the optimization of all the active materials relating to cell devices. However, many challenges hinder the practical application of QDSSCs, such as achieving higher power conversion efficiency, long-term stability, and large-scale production. Future works should focus on improving the power conversion efficiency of the solar cells as follows:

a. Designing new semiconductor QDs with a large wavelength range of optical absorption in terms of

b. quantum confinement.

c. Getting MEG effect enhancement of QDs by reducing the threshold energy.

d. Constructing suitable porosity for photoelectrodes to improve the loading of QDs on photoanode to increase the light harvesting efficiency of QDs.

e. Minimizing the charge recombination taking place at the QD- and photoanode-electrolyte interfaces.

f. Increasing electron mobility and device stability.

g. Reducing fabrication costs.

Solar cells using QDs have already exhibited high efficiency of conversion of light energy into electrical energy. However, commercialization of QDSSCs in large scale has yet to be realized. With the recent advances in the study of semiconductor QDs, we expect QDSSC will compete with silicon solar cell in the future.

\section{REFERENCES}

[1] Suait M S, Rahman M Y A, Ahmad A. Review on polymer electrolyte in dye-sensitized solar cells (DSSCs). Sol Energy 2015; 115: 452-470.

[2] Holdren J P. Science and technology for sustainable well-being. Science 2008; 456: 424-434.

[3] Lior N. Energy resources and use: the present situation and possible paths to the future. Energy 2008; 33: 842-857. 
[4] Barnham K W J, Mazzer M, Clive B. Resolving the energy crisis: nuclear or photovoltaics. Nat Mater 2006; 5: 161-164.

[5] Meyer G J. Molecular approaches to solar energy conversion with coordination compounds anchored to semiconductor surfaces. InorgChem 2005; 44: 6852-6864.

[6] Arrechea S, Molina-Ontoria A, Aljarilla A, et al. New acceptor-??-porphyrin-??-acceptor systems for solutionprocessed small molecule organic solar cells. Dyes Pigments 2015; 12: 1109-1117.

[7] Panda M K, Ladomenou K, Coutsolelos AG. Porphyrins in bio-inspired transformations: Light-harvesting to solar cell. CoordChem Rev 2012; 256: 2601-2627.

[8] Ali A, Cheow S L, Azhari A W, et al. Enhancing crystalline silicon solar cell efficiency with SixGe1-x layers. Results in Physics 2017; 7: 225-232.

[9] Eminian C, Haug F J, Cubero O, et al. Photocurrent enhancement in thin film amorphous silicon solar cells with silver nanoparticles. Prog. Photovolt: Res. Appl. 2011; 19: 260-265.

[10] Romeo A, Terheggen M, Abou-Ras D, et al. Development of Thin-film Cu(In,Ga)Se2 and CdTe Solar Cells. Prog. Photovolt: Res. Appl. 2004; 12: 93-111.

[11] Jackson P, Hariskos D, Lotter E, et al. New world record efficiency for $\mathrm{Cu}(\mathrm{In}, \mathrm{Ga}) \mathrm{Se} 2$ thin-film solar cells beyond 20\%. Prog. Photovolt: Res. Appl.2011; 19: 894-897.

[12] Ali N,Hussain A, Ahmed R, et al. Advances in nanostructured thin film materials for solar cell applications. Renew. Sustainable Energy Rev. 2016; 59: 726-737.

[13] Rho W Y, Jeon H, Kim H S, et al. Recent Progress in Dye-Sensitized Solar Cells for Improving Efficiency: $\mathrm{TiO}_{2}$ Nanotube Arrays in Active Layer. J Nanomater 2015; 2015: 247689.

[14] Shrotriya V, Li G, Yao Y, et al. Accurate measurement and characterization of organic solar cells. Adv. Funct. Mater. 2006; 16: 2016-2023.

[15] Zheng Z, Ji H, Yu P, et al. Recent Progress towards Quantum Dot Solar Cells with Enhanced Optical Absorption, Nanoscale Res. Lett. 2016; 11: 266.

[16] Xue G, Guo Y, Yu T, et al. Degradation mechanisms investigation for long-term thermal stability of dyesensitized solar cells. Int. J. Electrochem. Sci. 2012; 7: 1496-1511.

[17] Das R, Dhar N,Bandyopadhyay A, et al. Size dependent magnetic and optical properties in diamond shaped graphene quantum dots: A DFT study. J. Phys.Chem. Solids 2016; 99: 34-42.

[18] Sambur J B, Parkinson B A. CdSe/ZnS Core/Shell Quantum Dot Sensitization of Low Index $\mathrm{TiO}_{2}$ Single Crystal Surfaces. J. Am. Chem. Soc.2010; 132: 2130-2131.

[19] Toyoda T, Yindeesuk W, Kamiyama K, et al. Adsorption and Electronic Structure of CdSe Quantum Dots on Single Crystal ZnO: A Basic Study of Quantum Dot-Sensitization System. J. Phys. Chem. C 2016; 120: $16367-16376$.

[20] Ahmed R, Zhao L, Mozer A J, et al., Enhanced Electron Lifetime of CdSe/CdS Quantum Dot (QD) Sensitized Solar Cells Using ZnSe Core-Shell Structure with Efficient Regeneration of Quantum Dots. J. Phys. Chem. C 2015; 119: 2297-2307.

[21] Bhambhani P, Alvi P A. A Systematic Study of the Optical Properties of Co-, and Ni- Doped Colloidal Cadmium Sulphide Nanoparticles. J. Optoelectronics Engineering 2016; 4: 11-16.

[22] Raphael E, Jara E H, Schiavon M A. Optimizing photovoltaic performance in CuInS2 and CdS quantum dotsensitized solar cells by using an agar-based gel polymer electrolyte. RSC Adv. 2017; 7: 6492-6500.

[23] Kohnehpoushi S, Eskandari M, Nejand B A, et al. Numerical calculation of visible light absorption enhancement of CdSe-quantum dot-sensitized $\mathrm{TiO}_{2}$ nanorod periodic array as photoanode. J. Phys. D: Appl. Phys.2017; 50: 075102.

[24] Yi J, Duan Y, Liu C, et al. PbS Quantum Dots Sensitized $\mathrm{TiO}_{2}$ Solar Cells Prepared by Successive Ionic Layer Absorption and Reaction with Different Adsorption Layers. J. Nanosci. Nanotechnol. 2016; 16: 3904-3908.

[25] Zhang J, Gao J, Church C P, et al. Klimov and Matthew C. Beard, PbSe Quantum Dot Solar Cells with More than 6\% Efficiency Fabricated in Ambient Atmosphere. Nano Lett. 2014; 14: 6010-6015.

[26] Beard M C, Johnson J C, Luther J M, et al. Multiple exciton generation in quantum dots versus singlet fission in molecular chromophores for solar photon conversion. Phil. Trans. R. Soc. A 2015; 373: 20140412.

[27] Shang Y, Hao S, Yang C, et al. Enhancing Solar Cell Efficiency Using Photon Upconversion Materials. Nanomaterials 2015; 5:1782-1809.

[28] Williams K J, Nelson C A, Yan X, et al. Hot Electron Injection from Graphene Quantum Dots to $\mathrm{TiO}_{2}$. ACS Nano 2013; 7: 1388-1394.

[29] Nozik A J. Nanoscience and nanostructures for photovoltaics and solar fuels. Nano Lett 2010; 10: 2735-2741.

[30] Semonin O E, Luther J M, Choi S, et al. Peak external photocurrent quantum efficiency exceeding $100 \%$ via MEG in a quantum dot solar cell. Science 2011; 334: 1530-1533.

[31] Kouhnavard M, Ikeda S, Ludin N A, et al. A review of semiconductor materials as sensitizers for quantum dotsensitized solar cells. Renew. Sustainable Energy Rev.2014; 37: 397-407.

[32] Vogel R, Hoyer P, Weller H. Quantum-sized PbS, CdS, Ag2S, Sb2S3 and Bi2S3 particles as sensitizers for various nanoporous wide-bandgap semiconductors. J. Phys Chem 1994; 98: 3183-3188.

[33] Wang X, Koleilat G I, Tang J, et al. Tandem colloidal quantum dot solar cells employing a graded recombination layer. J. Nat. Photon 2011; 5: 480-484.

[34] Turko B I, Kapustianyk V B, Rudyk V P, et al. Thermal Conductivity of Zinc Oxide Micro- and Nanocomposites. J. Nano- Electron. Phys. 2016; 8: 02004. 
[35] Arthur E, Lucky A. Synthesis and Characterization of CdS and CdSe Quantum Dots by UV-VIS Spectroscopy. JETEAS 2013; 4: 273-280.

[36] Mushonga P, Onani M O, MadieheA M, et al. Indium Phosphide-Based Semiconductor Nanocrystals and Their Applications. J. Nanomater. 2011; 2012: 869284.

[37] Bhambhani P, Kabra K, Kumar D, et al. Fabrication of hierarchical flower shaped PbS crystals via hydrothermal and microwave routes. Adv. Mat. Res. 2015; 1105: 88-92.

[38] Thambidurai M, Jang Y, Shapiro A, et al. High performance infrared photodetectors up to $2.8 \mu \mathrm{m}$ wavelength based on lead selenide colloidal quantum dots. Opt Mater Express 2017; 7: 291171.

[39] Asano H, Omata T. Design of cadmium-free colloidal II-VI semiconductor quantum dots exhibiting RGB emission. AIP Advances 2017; 7: 045309.

[40] Lee J R I, Meulenberg R W, Hanif K M, et al. Experimental Observation of Quantum Confinement in the Conduction Band of CdSe Quantum Dots. Phys Rev Lett 2007; 98; 146803.

[41] Tian J, Cao G. Semiconductor quantum dot-sensitized solar cells. Nano Rev. 2013; 4: 22578.

[42] Woo J S, Hong K J, Hyunsoo K, et al. ZnS over layer on insitu chemical bath deposited CdS quantum dotassembled $\mathrm{TiO}_{2}$ films for quantum dot-sensitized solar cells. J CurrApplPhys 2012; 12: 1459-1464.

[43] Chen J, Lei W, Deng W Q. Reduced Charge recombination in a co-sensitized quantum dot solar cell with two different sizes of CdSe quantum dot. Nanoscale 2011; 3: 674-677.

[44] Prabakar K, Minkyu S, Inyoung S, et al. CdSe quantum dots co-sensitized $\mathrm{TiO}_{2}$ photoelectrodes: particle size dependent properties. J. Phys. D: Appl. Phys. 2010; 43: 012002.

[45] Gong J, Liang J, Sumathy K. Review on dye sensitized solar cells (DSSCs): fundamental concepts and novel materials. Renew. Sustainable Energy Rev.2012; 16: 5848-5860.

[46] Tang H, Prasad K, Sanjines R, et al. Electrical and optical properties of $\mathrm{TiO}_{2}$ anatase thin films. J. Appl. Phy. 1994; 75: 2042-2047.

[47] Birel O, Nadeem S, Duman H. Porphyrin-Based Dye-Sensitized Solar Cells (DSSCs): a Review. J Fluoresc 2017; 27: $1075-1085$.

[48] Das P, Sengupta D, Mondal B, et al. A review on metallic ion and non-metal doped titania and zinc oxide photoanodes for dye sensitized solar cells, Rev. Adv. Sci. Eng. 2015; 4: 271-290.

[49] Liu X, Liu J F Y, Lin T. Progress in nanostructured photoanodes for dye-sensitized solar cells. Front Mater Sci. 2016; 10: 225-237.

[50] Dai S, Wu, Sakai T, et al. Preparation of highly crystalline $\mathrm{TiO}_{2}$ nanostructures by acid-assisted hydrothermal treatment of hexagonal-structured nanocrystallinetitania/ cetyltrimethyammonium bromide nanoskeleton. Nanoscale Res. Lett. 2010; 5: 1829-1835.

[51] Serikov T M, Ibrayev N K, Smagulov Z K, et al. Influence of annealing on optical and photovoltaic properties of nanostructured $\mathrm{TiO}_{2}$ films. IOP Conference Series: Materials Science and Engineering 2017; 168: 1-6.

[52] Zhang J, Zhou P, Liu J. New understanding of the difference of photocatalytic activity among anatase, rutile and brookite $\mathrm{TiO}_{2}$. Phys. Chem. Chem. Phys.2014; 16: 20382-20386.

[53] Park N, Lagemaat J V D, Frank A J. Comparison of dye-sensitized rutile- and anatase-based $\mathrm{TiO}_{2}$ solar cells. J. Phys. Chem. B 104, (2000), 8989-8994.

[54] Lagemaat J V D, Park N G, Frank A J. Influence of electrical potential distribution, charge transport, and recombination on the photopotential and photocurrent conversion efficiency of dye-sensitized nanocrystallne $\mathrm{TiO}_{2}$ solar cells: A study by electrical impedance and optical modulation techniques. J. Phys. Chem. B 104, (2000) 2044-2052.

[55] Feng X, Zhu K, Frank A J, et al. Rapid charge transport in dye-sensitized solar cells made from vertically aligned single-crystal rutile TiO2 nanowires. Angew. Chem.2012; 124: 2781-2784.

[56] Feng X, Shankar K, Varghese O K, etal.Vertically aligned single crystal $\mathrm{TiO}_{2}$ nanowire arrays grown directly on transparent conducting oxide coated glass: Synthesis details and applications. Nano Lett. 2008; 8: 3781-3786.

[57] Zhou J, Song B, Zhao G, et al. $\mathrm{TiO}_{2}$ nanorod arrays sensitized with CdS quantum dots for solar cell applications: Effects of rod geometry on photoelectrochemical performance. Appl. Phys. A Mater. Sci. Process. 2012; 107: $321-$ 331.

[58] Wang M, Bai J, Formal F L, et al. Solid-state dye-sensitized solar cells using ordered $\mathrm{TiO}_{2}$ nanorods on transparent conductive oxide as photoanodes. J. Phys. Chem. C 2012; 116: 3266-3273.

[59] Lee S, Park I J, Kim D H, et al. Crystallographically preferred oriented $\mathrm{TiO}_{2}$ nanotube arrays for efficient photovoltaic energy conversion. Energy Environ. Sci. 2012; 5: 7989-7995.

[60] Martinson A B F, Elam J W, Hupp J T, et al. ZnO nanotube based dye-sensitized solar cells. Nano Lett. 2007; 7: $2183-2187$.

[61] Kolay A, Kumar P N, Kumar S K, et al. Titanium oxide morphology controls charge collection efficiency in quantum dot solar cells. Phys. Chem. Chem. Phys.2017; 19: 4607-4617.

[62] $\mathrm{Lu} \mathrm{Y} \mathrm{B,} \mathrm{Li} \mathrm{L,} \mathrm{Su} \mathrm{S} \mathrm{C,} \mathrm{et} \mathrm{al.} \mathrm{A} \mathrm{novel} \mathrm{TiO}_{2}$ nanostructure as photoanode for highly efficient CdSe quantum dotsensitized solar cells. RSC Adv. 2017; 7: 9795-9802.

[63] Seol M, Kim H, Tak Y, et al. Novel nanowire array based highly efficient quantum dot sensitized solar cell. Chem. Commun.2010; 46: 5521-5523.

[64] Tian J, Zhang Q, Uchaker E, et al. Constructing ZnO nanorod array photoelectrodes for highly efficient quantum dot sensitized solar cells. J. Mater. Chem. A 2013; 1: 6770-6775.

[65] Chetia T R, Ansari M S, Qureshi M.Ethyl Cellulose and Cetrimonium Bromide Assisted Synthesis of Mesoporous, Hexagon Shaped ZnONanodisks with Exposed $\pm\{0001\}$ Polar Facets for Enhanced Photovoltaic Performance in Quantum Dot Sensitized Solar Cells. ACS Appl. Mater. Interfaces 2015; 7: 13266-13279. 
[66] Lan Z, Liu L, Huang M, et al. Preparation of nano-flower-like SnO2 particles and their applications in efficient CdS quantum dots sensitized solar cells. J. Mater. Sci.: Mater. Electron. 2015; 26: 7914-7920.

[67] Park J, Sajjad M T, Jouneau P H, et al. Efficient eco-friendly inverted quantum dot sensitized solar cells. J. Mater. Chem. A 2016; 4: 827-837.

[68] Feng H L, Wu W Q, Rao H S, et al. Three-Dimensional $\mathrm{TiO}_{2} / \mathrm{ZnO}$ Hybrid Array as a Heterostructured Anode for Efficient Quantum-Dot-Sensitized Solar Cells. ACS Appl. Mater. Interfaces 2015; 7: 5199-5205.

[69] Du Z, Zhang H, Bao H, et al. Optimization of $\mathrm{TiO}_{2}$ photoanode films for highly efficient quantum dot-sensitized solar cells. J. Mater. Chem. A 2014; 2: 13033-13040.

[70] Zhou H, Li L, Jiang D, et al. Anatase $\mathrm{TiO}_{2}$ nanosheets with exposed highly reactive (001) facets as an efficient photoanode for quantum dot-sensitized solar cells. RSC Adv. 2016; 6: 67968-67975.

[71] Zhang W, Zeng X, Wang H, et al.High-yield synthesis of "oriented attachment" $\mathrm{TiO}_{2}$ nanorods as superior building blocks of photoanodes in quantum dot sensitized solar cells.RSC Adv. 2016; 6: 33713-33722.

[72] Huang H, Pan L, Lim C K, et al. Tan, Hydrothermal Growth of $\mathrm{TiO}_{2}$ Nanorod Arrays and In Situ Conversion to Nanotube Arrays for Highly Efficient Quantum Dot-Sensitized Solar Cells. Small 2013; 9: 3153-3160.

[73] Rao H S, Wu W Q, Liu Y, et al. CdS/CdSe co-sensitized vertically aligned anatase $\mathrm{TiO}_{2}$ nanowire arrays for efficient solar cells. Nano Energy 2014; 8: 1-8.

[74] Cao Y, Dong Y J, Chen $\mathrm{H}$ Y, et al. CdS/CdSe co-sensitized hierarchical $\mathrm{TiO}_{2}$ nanofiber/ZnOnanosheetheterojunctionphotoanode for quantum dot-sensitized solar cells. RSC Adv 2016; 6: 78202-78209.

[75] Tian J, Cao G. Semiconductor quantum dot-sensitized solar cells. Nano Rev. 2013; 4: 22578

[76] Tubtimtae A, Lee M W, Wang G J. Ag2Se quantum-dot sensitized solar cells for full solar spectrum light harvesting. J. Power Sources 2011; 196: 6603-6608.

[77] Esparza D, Zarazua I, Lopez-Luke T, et al. Photovoltaic Properties of Bi2S3 and CdS Quantum Dot Sensitized $\mathrm{TiO}_{2}$ Solar Cells. Electrochim. Acta 2015; 180: 486-492.

[78] Mu L, Liu C, Jia J, et al. Dual post-treatment: a strategy towards high efficiency quantum dot sensitized solar cells. J. Mater. Chem. A 2013; 1: 8353-8357.

[79] Choi Y, Seol M, Kim W, et al. Chemical Bath Deposition of Stoichiometric CdSe Quantum Dots for Efficient Quantum-Dot-Sensitized Solar Cell Application. J. Phys. Chem. C 2014; 118: 5664-5670.

[80] Yang J,Zhong X. CdTe based quantum dot sensitized solar cells with efficiency exceeding 7\% fabricated from quantum dots prepared in aqueous media. J. Mater. Chem. A 2016; 4: 16553-16561.

[81] Pan Z, Mora-Sero I, Shen Q, et al. High-efficiency "green" quantum dot solar cells. J. Am. Chem. Soc. 2014; 136: 9203-9210.

[82] Chang J Y, Li C H, Chiang Y H, et al. Toward the Facile and Ecofriendly Fabrication of Quantum Dot-Sensitized Solar Cells via ThiolCoadsorbent Assistance. ACS Appl. Mater. Interfaces 2016; 8: 18878-18890.

[83] Bai B, Kou D, Zhou W, et al. Quaternary Cu2ZnSnS4 quantum dot-sensitized solar cells: Synthesis, passivation and ligand exchange. J. Power Sources 2016; 318: 35-40.

[84] Lee S H, Jung C, Jun Y, et al. Synthesis of colloidal InAs/ZnSe quantum dots and their quantum dot sensitized solar cell (QDSSC) application. Opt. Mater. 2015; 49: 230-234.

[85] Duan J, Tang Q, He B, et al. Efficient In2S3 Quantum dot-sensitized Solar Cells: A Promising Power Conversion Efficiency of 1.30\%. Electrochim. Acta 2014; 139: 381-385.

[86] Yan S, Zhao P, Zhao X, et al. InP and Sn:InP based quantum dot sensitized solar cells. J. Mater. Chem. A 2015; 3 : 21922-21929.

[87] Gonzalez-Pedro V, Sima C, Marzari G, et al. High performance PbS Quantum Dot Sensitized Solar Cells exceeding 4\% efficiency: the role of metal precursors in the electron injection and charge separation. Phys. Chem. Chem. Phys. 2013; 15: 13835-13843.

[88] Chang L Y, Lunt R R, Brown P R, et al. Low-temperature solution-processed solar cells based on PbS colloidal quantum dot/CdSheterojunctions. Nano Lett 2013; 13: 994-999.

[89] Benehkohal N P, Gonzalez-Pedro V, Boix P P, et al. Colloidal PbS and PbSeS Quantum Dot Sensitized Solar Cells Prepared by Electrophoretic Deposition. J. Phys. Chem. C 2012; 116: 16391-16397.

[90] Seo H, Wang Y, Uchida G, et al. Analysis on the effect of polysulfide electrolyte composition for higher performance of Si quantum dot-sensitized solar cells. Electrochim. Acta 2013; 95: 43-47.

[91] Zhong Y, Zhang H, Pan D, et al. Graphene quantum dots assisted photovoltage and efficiency enhancement in CdSe quantum dot sensitized solar cells. J. Energy Chem. 2015; 24: 722-728.

[92] Yu X Y, Liao J Y, Qiu K Q, et al. Carrier Generation and Collection in CdS/CdSe-Sensitized SnO2 Solar Cells Exhibiting Unprecedented Photocurrent Densities. ACS Nano 2011; 5: 9494-9500.

[93] Wang Q, Li S, Qiao J, et al. CdS-CdSe (CdTe) core-shell quantum dots sensitized $\mathrm{TiO}_{2}$ nanotube array solar cells. Sol. Energy Mater. Sol. Cells 2015; 132: 650-654.

[94] Bang J H, Kamat P V. Quantum dot sensitized solar cells. A tale of two semiconductor nanocrystals: CdSe and CdTe. ACS Nano 2009; 3: 1467-1476.

[95] Wang J, Mora-Sero I, Pan Z, et al. Core/shell colloidal quantum dot exciplex states for the development of highly efficient quantum-dot-sensitized solar cells. J. Am. Chem. Soc. 2013; 135: 15913-15922.

[96] Yuan D, Xiao L, Luo J, High-Throughput Screening and Optimization of Binary Quantum Dots Cosensitized Solar Cell. ACS Appl. Mater. Interfaces 2016; 8: 18150-18156.

[97] Jiao S, Wang J, Shen Q, et al. Surface engineering of PbS quantum dot sensitized solar cells with a conversion efficiency exceeding 7\%. J. Mater. Chem. A 2016; 4: 7214-7221. 
[98] Zhou N, Yang Y, Huang X, et al. Panchromatic Quantum-Dot-Sensitized Solar Cells Based on a Parallel Tandem Structure. Chemsuschem 2013; 6: 687-692.

[99] Sahasrabudhe A, Bhattacharyya S. Dual Sensitization Strategy for High-Performance Core/Shell/Quasi-shell Quantum Dot Solar Cells. Chem. Mater. 2015; 27: 4848-4859.

[100] Li T L, Lee Y L, Teng H. High-performance quantum dot-sensitized solar cellsbased on sensitization with CuInS2 quantum dots/CdSheterostructure. Energy Environ. Sci. 2012; 5: 5315-5324.

[101] Wang Y Q, Rui Y C, Zhang Q H, et al. A Facile in Situ Synthesis Route for CuInS2 Quantum-Dots/In2S3 CoSensitized Photoanodes with High Photoelectric Performance. ACS Appl. Mater. Interfaces 2013; 5: 11858-11864.

[102] Basit M A, Abbas M A, Jung E S, et al. Strategic PbS quantum dot-based multilayered photoanodes for high efficiency quantum dot-sensitized solar cells. Electrochim. Acta, 2016; 211: 644-651.

[103] Jiao S, Shen Q, Mora-Sero I, et al. Band Engineering in Core/Shell ZnTe/CdSe for Photovoltage and Efficiency Enhancement in Exciplex Quantum Dot Sensitized Solar Cells. ACS Nano 2015; 9: 908-915.

[104] Lee Y L, Lo Y S. Highly Efficient Quantum-Dot-Sensitized Solar Cell Based on Co-Sensitization of CdS/CdSe. Adv. Funct. Mater. 2009; 19: 604-609.

[105] Zhang Y, Zhu J, Yu X, et al. The optical and electrochemical properties of CdS/CdSe co-sensitized $\mathrm{TiO}_{2}$ solar cells prepared by successive ionic layer adsorption and reaction processes. Sol. Energy 2012; 86: 964-971.

[106] Pan Z, Zhang H, Cheng K, et al. Highly Efficient Inverted Type-I CdS/CdSe Core/Shell Structure QD-Sensitized Solar Cells. ACS Nano 2012; 6: 3982-3991.

[107] Halim M A. Review harnessing Sun'senergy with quantum dots based next generation solar cell. Nanomaterials 2013; 3: 22-47.

[108] Wu M, Lin X, Wang Y, et al. Counter electrode materials combined with redox couples in dye- and quantum dotsensitized solar cells. J. Mater. Chem. A2015; 3: 19638-19656.

[109] Yella A, Lee H W, Tsao H N, et al. Porphyrin-sensitized solar cells with cobalt (II/III)-based redox electrolyte exceed 12 percent efficiency.Science 2011; 334: 629-634.

[110] Shalom M, Dor S, Ruhle S, et al. Core/CdS Quantum Dot/Shell Mesoporous Solar Cells with Improved Stability and Efficiency Using an Amorphous $\mathrm{TiO}_{2}$ Coating. J. Phys. Chem. C 2009; 113: 3895-3898.

[111] Duan J, Zhang H, Tang Q, et al. ecent advances in critical materials for quantum dot-sensitized solar cells: a review, J. Mater. Chem. A 2015; 3: 17497-17510.

[112] Hod I, Zaban A. Materials and Interfaces in Quantum Dot Sensitized Solar Cells: Challenges, Advances and Prospects. Langmuir 2014; 30: 7264-7273.

[113] Liao Y, Zhang J, Liu W, et al. Enhancing the efficiency of CdS quantum dot-sensitized solar cells via electrolyte engineering. Nano Energy 2015; 11: 88-95.

[114] Wei H, Wang G, Shi J, et al. Fumed SiO2 modified electrolytes for quantum dot sensitized solar cells with efficiency exceeding 11\% and better stability. J.Mater. Chem. A 2016; 4: 14194-14203.

[115] Jiang G, Pan Z, RenZ,et al. Poly(vinyl pyrrolidone): a superior and general additive in polysulfide electrolytes for high efficiency quantum dot sensitized solar cells. J. Mater. Chem. A 2016; 4: 11416-11421.

[116] Chou C Y, Lee C P, Vittal R, et al. Efficient quantum dot-sensitized solar cell with polystyrene-modified $\mathrm{TiO}_{2}$ photoanode and with guanidine thiocyanate in its polysulfide electrolyte. J. Power Sources 2011; 96: 6595-6602.

[117] Li L, Yang X, Gao J, et al. Highly efficient CdS quantum dot-sensitized solar cells based on a modified polysulfide electrolyte. J. Am. Chem. Soc.2011; 133: 8458-8460.

[118] Ning Z, Yuan C, Tian H, et al. Type-II colloidal quantum dot sensitized solar cells with a thiourea based organic redox couple. J. Mater. Chem. 2012; 22: 6032-6037.

[119] Meng K, Surolia P K, Byrne O, et al. Quantum dot and quantum dot-dye co-sensitized solar cells containing organic thiolate-disulfide redox electrolyte. J. Power Sources 2015; 275: 681-687.

[120] Jovanovski V, Gonzalez-Pedro V, Gimenez S, et al. A sulfide/polysulfide-based ionic liquid electrolyte for quantum dot-sensitized solar cells. J. Am. Chem. Soc. 2011; 133: 20156-20159.

[121] Feng W, Li Y, Du J, W. Wang, et al. Highly efficient and stable quasi-solid-state quantum dot-sensitized solar cells based on a superabsorbent polyelectrolyte. J. Mater. Chem. A 2016; 4: 1461-1468.

[122] Huo Z, Tao L, Wang S, et al. A novel polysulfide hydrogel electrolyte based on low molecular mass organogelator for quasi-solid-state quantum dot-sensitized solar cells. J. Power Sources 2015; 284: 582-587.

[123] Park J P, Heo J H, Im S H, et al. Highly efficient solid-state mesoscopicPbS with embedded CuS quantum dotsensitized solar cells. J. Mater. Chem. A 2016; 4: 785-790

[124] Duan J, Tang Q, Sun Y, et al. Solid-state electrolytes from polysulfide integrated polyvinylpyrrolidone for quantum dot-sensitized solar cells. RSC Adv. 2014; 4: 60478-60483.

[125] Yang Y, Wang W.A new polymer electrolyte for solid-state quantum dot sensitized solar cells. J. Power Sources 2015; 285: 70-75.

[126] Wang S, Tian J,Recent advances in counter electrodes of quantum dot-sensitized solar cells. RSC Adv.2016; 6: 90082-90099.

[127] Ye M, Chen C, Zhang N, et al. Quantum-Dot Sensitized Solar Cells Employing Hierarchical Cu2S Microspheres Wrapped by Reduced Graphene Oxide Nanosheets as Effective Counter Electrodes. Adv. Energy Mater.2014; 4: 1301564.

[128] Liu L, Liu C, Fu W, et al. Phase Transformations of Copper Sulfide Nanocrystals: Towards Highly Efficient Quantum-Dot-Sensitized Solar Cells. ChemPhysChem 2016; 17: 771-776.

[129] Venkata-Haritha M, Gopi C V V M, Young-Seok L, et al. Controlled growth of a nanoplatelet-structured copper sulfide thin film as a highly efficient counter electrode for quantum dot-sensitized solar cells. RSC Adv.2016; 6: 45809-45818. 
[130] Shen C, Sun L, Koh Z Y, et al. Cuprous sulfide counter electrodes prepared by ion exchange for high-efficiency quantum dot sensitized solar cells. J. Mater. Chem. A 2014; 2: 2807-2813.

[131] Fang B, Kim M, Fan S Q, et al. Facile synthesis of open mesoporous carbon nanofibers with tailored nanostructure as a highly efficient counter electrode in CdSe quantum-dot-sensitized solar cells. J. Mater. Chem. 2011; 21: 87428748.

[132] Dong J, Jia S, Chen J, et al. Nitrogen-doped hollow carbon nanoparticles as efficient counter electrodes in quantum dotsensitized solar cells. J. Mater. Chem. 2012; 22: 9745-9750

[133] Fan S Q, Fang B, Kim J H, et al. Hierarchical nanostructured spherical carbon with hollow core/mesoporous shell as a highly efficient counter electrode in CdSe quantum-dot-sensitized solar cells. Appl. Phys. Lett.2010; 96: 063501 .

[134] Jiang Y, Yu B B, Liu J, et al. Boosting the Open Circuit Voltage and Fill Factor of QDSSCs Using Hierarchically Assembled ITO@Cu2S Nanowire Array Counter Electrodes. Nano Lett.2015; 15: 3088-3095.

[135] Eskandari M, Ghahary R, Shokri M, et al. Zinc oxide/copper sulfide nanorods as a highly catalytic counter electrode material for quantum dot sensitized solar cells. RSC Adv.2016; 6: 51894-51899.

[136] Gopi C V V M, Venkata-Haritha M, Lee Y S, et al. ZnOnanorods decorated with metal sulfides as stable and efficient counter-electrode materials for high-efficiency quantum dot-sensitized solar cells. J. Mater. Chem. A 2016; 4: 8161-8171.

[137] Meng K, Chen G, Thampi K R, Metal chalcogenides as counter electrode materials in quantum dot sensitized solar cells: a perspective. J. Mater. Chem. A 2015; 3: 23074-23089. 